\title{
Utilización del uretroscopio flexible para extracción de cuerpos extraños
}

\author{
Diz Rodríguez R, Vírseda Chamorro M, Martínez Benito Mํㅗㄹ, Quijano Barroso P, \\ Sáenz Benito D, Paños Lozano P.
}

Servicio de Urología. Hospital Central de la Defensa. Madrid.

Actas Urol Esp. 2007;31(10):1197

$\mathrm{P}$ aciente de 92 años portador de sonda vesical a permanencia por retención urinaria. Deterioro cognitivo severo. Cardiopatía que precisa anticoagulación, insuficiencia respiratoria que precisa oxigenoterapia.

Acude a urgencias por rotura accidental de la sonda. En radiografia simple de abdomen se delinea parte de la sonda dentro de la uretra (Fig. 1).

Se realiza endoscopia con el uretroscopio flexible comprobándose la presencia de un fragmento de sonda en la uretra anterior (Fig. 2). Debido al mal estado

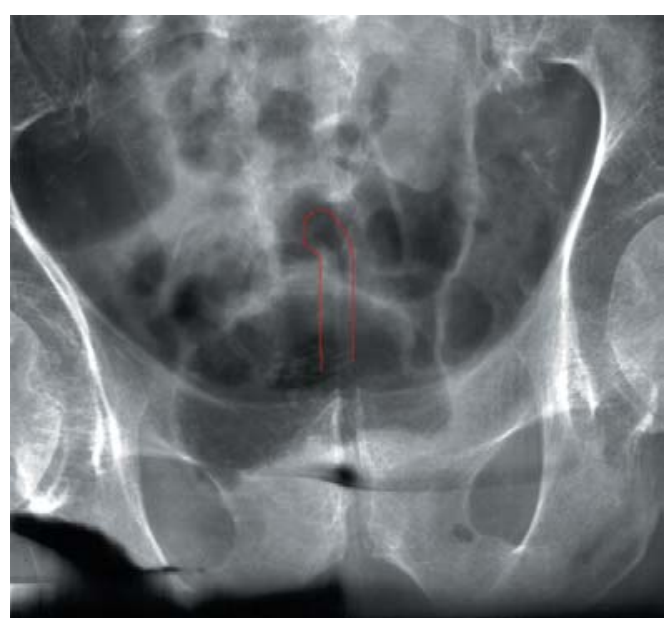

FIGURA 1

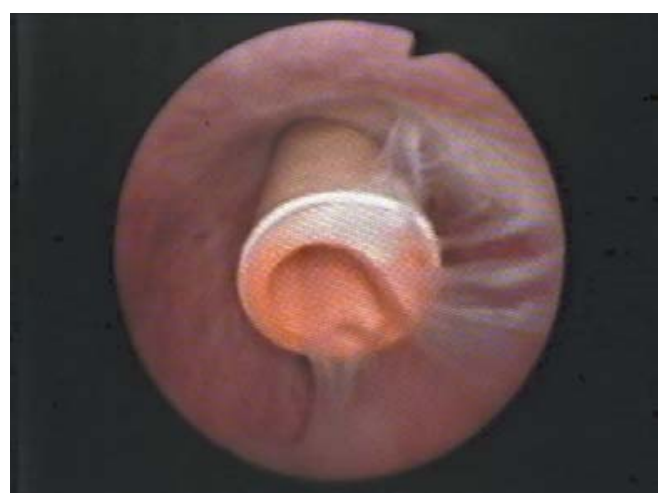

FIGURA 2 general del paciente, se aprovecha la uretroscopia y en la misma cama del paciente y a través del canal auxiliar del instrumento se introduce una pinza de cuerpos extraños, logrando atrapar y extraer el fragmento de sonda vesical (Figs. 3 y 4).

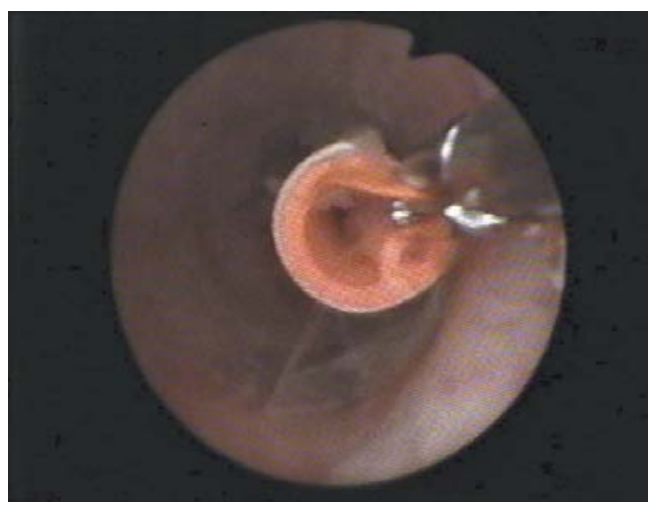

FIGURA 3

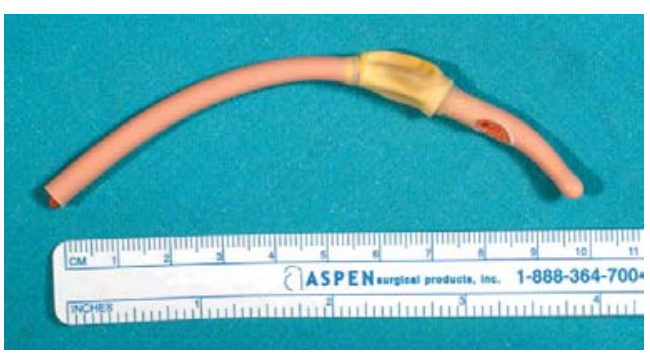

FIGURA 4

Consideramos que la uretroscopia flexible es una técnica poco agresiva para el paciente y que puede solucionar muchos problemas del tracto urinario inferior.

Correspondencia autor: Dr. M. Vírseda Chamorro

Servicio de Urología. Hospital Central de la Defensa. Madrid Plaza del Ejército s/n. 28007 Madrid.

Tel.: 914228000

E-mail autor: bgmeli@terra.es

Información artículo: Imágenes en Urología

Trabajo recibido: septiembre 2006

Trabajo aceptado: octubre 2006 